\title{
Chemistry of Unprotected Amino Acids in Aqueous Solution: Direct Bromination of Aromatic Amino Acids with Bromoisocyanuric Acid Sodium Salt under Strong Acidic Condition
}

\author{
Yuusaku Yokoyama, * Tomotsugu Yamaguchi, Masanori Sato, Eri KobaYashi, Yasuoki MuraKami, \\ and Hiroaki OKunO
}

Department of Pharmaceutical Sciences, Toho University; 2-2-1 Miyama, Funabashi, Chiba 274-8510, Japan. Received September 5, 2006; accepted October 4, 2006; published online October 6, 2006

\begin{abstract}
Brominations of unprotected aromatic amino acids such as phenylalanine, tyrosine, and glycine, with bromoisocyanuric acid mono sodium salt (BICA-Na) were conducted in $60 \%$ aq. $\mathrm{H}_{2} \mathrm{SO}_{4}$ at $0{ }^{\circ} \mathrm{C}$ to give a mixture of mono-brominated products in good yield. Unexpectedly, meta-bromophenylglycine was obtained as main product accompanied by ortho- and para-substituted products, while phenylalanine gave only ortho- and para-substituted products. Bromination of 2-phenylethylamine or benzylamine showed a tendency similar to the corresponding amino acids.
\end{abstract} water

Key words aromatic amino acid; bromination; electrophilic aromatic substitution; bromoisocyanuric acid mono sodium salt;

In biological systems, transformation of amino acids to biologically important products proceeds efficiently through the action of enzymes without requiring protection of reactive functional groups. However, only a few studies ${ }^{1-11)}$ of synthetic reactions using unprotected (free) amino acids have been reported. Most of the synthetic transformations to natural products, pharmaceuticals, and chiral auxiliaries have been performed ${ }^{12-15)}$ with protected amino acids to increase solubility in organic solvents and avoid side reactions. We have reported ${ }^{16,17)}$ a three-step synthesis of optically active clavicipitic acids (6), ergot alkaloids, from 4-bromoindole (1) and $d l$-serine (2) that involved a reaction of unprotected amino acids in aqueous media as a key step (Chart 1). Thus, Pd-catalyzed reaction of 4-bromotryptophan $[S-(\mathbf{3})]$ with 1,1 dimethylallylalcohol (4) under strong basic conditions selectively yielded the Heck product (5), which spontaneously cyclized to give clavicipitic acids (6) in one pot. This route indicated that the reaction of unprotected amino acids in aqueous media showed promise for developing unique synthetic reactions.

Here, we present another reaction of free amino acids in aqueous media, e.g., the direct bromination of unprotected aromatic amino acids (7) under strong acidic conditions (Chart 2, Route A).

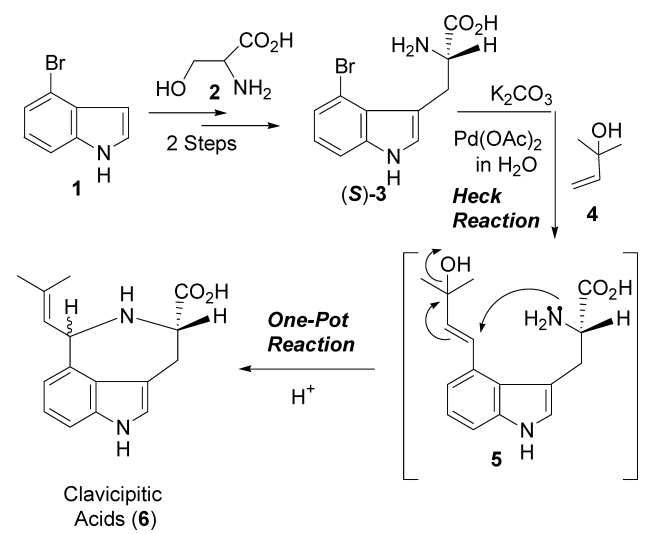

Chart 1. Three-Step Synthesis of Clavicipitic Acids (6)

\section{Results and Discussion}

Bromination of Phenylalanine An aromatic bromide is an important synthetic intermediate for the introduction of carbon side chain by palladium catalyzed cross-coupling reaction. ${ }^{18)}$ Generally, bromination of aromatic amino acid (7) is carried out after protection of the amino group, because amino acids are decomposed ${ }^{19-22)}$ by the attack of bromonium cations to a carboxyl or amino group $(\mathbf{1 0 a}$ or $\mathbf{1 0 b}$ in Route B of Chart 2). Direct bromination of unprotected aromatic amino acids, however, should be possible under strongly acidic conditions because the amino groups are protected by complete protonation to form $\mathbf{8}$. The choice of the brominating reagent is very important, because the reagent should be stable under strong acidic conditions in aqueous media. Bromoisocyanuric acid monosodium salt (BICA-Na, 11) was selected because it is used as a strong brominating reagent for electron deficient aromatic compounds in concentrated sulfuric acid. $^{23-26)}$

Initially, bromination of phenylalanine (15) was conducted in the presence of $1.1 \mathrm{eq}$ of BICA-Na (11). The reaction proceeded smoothly in $60 \% \mathrm{H}_{2} \mathrm{SO}_{4}$ under mild conditions $\left(0^{\circ} \mathrm{C}\right.$, $2 \mathrm{~h})$. The ortho- (16) and para-bromophenylalanine (17) were obtained in $36 \%$ and $58 \%$ yield, respectively (Table 1 , run 2). The total yield of mono-brominated products was very high $(94 \%)$, and separation of each products $(16,17)$ was easy by using the reverse phase (ODS) column chromatography. Furthermore, these products were not racemized despite the strong acidic conditions. We previously re-

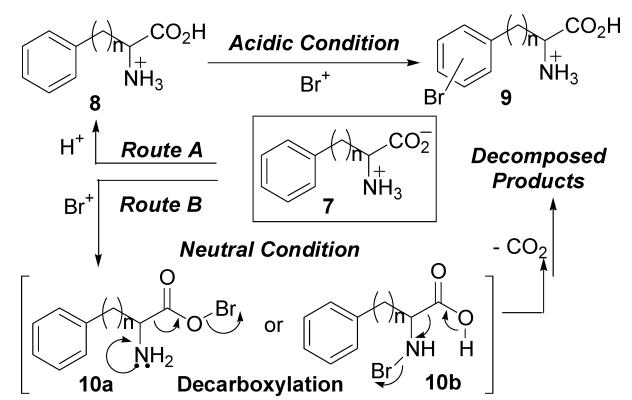

Chart 2. Direct Bromination of Aromatic Amino Acids 
Table 1. Bromination of L-Phenylalanine (15)

\begin{tabular}{|c|c|c|c|c|}
\hline \multirow{2}{*}{ Run } & \multirow{2}{*}{$\mathrm{H}_{2} \mathrm{SO}_{4}(\%)$} & \multicolumn{2}{|c|}{ Yield (\%) } & \multirow{2}{*}{$\begin{array}{c}15 \\
(\%)\end{array}$} \\
\hline & & 16 & 17 & \\
\hline 1 & 30 & 14 & 13 & 53 \\
\hline 2 & 60 & 36 & 58 & - \\
\hline 3 & 90 & 8 & 10 & 25 \\
\hline
\end{tabular}

ported $^{27)}$ that racemization and decomposition of free amino acids occurred easily in organic solvents under acidic and basic conditions. Although the direct bromination with vaporized $\mathrm{Br}_{2}$ has been reported, ${ }^{28)}$ the yield was law (total $65 \%$ ) in addition to the formation of considerable amount of isomeric mixture of dibromophenylalanine.

The concentration of $\mathrm{H}_{2} \mathrm{SO}_{4}$ was important in the reaction. For, in the case of $30 \% \mathrm{H}_{2} \mathrm{SO}_{4}$, starting material (15) was recovered in $53 \%$ yield accompanied by small amounts of mono-brominated products (Table 1 , run 1 ), and the $90 \%$ $\mathrm{H}_{2} \mathrm{SO}_{4}$ decomposed the products and starting material, leading to low recovery of products and starting material (Table 1 , run 3$)$.

The use of other acids (e.g., $48 \% \mathrm{HBr}, \mathrm{HBr}-\mathrm{CH}_{3} \mathrm{CO}_{2} \mathrm{H}$ ) and addition of an inorganic salt (e.g., $\mathrm{KBr}, \mathrm{CuBr}, \mathrm{CuBr}_{2}$ ) did not yield any products. This may be due to trapping of bromonium cation by bromide anion. Other organic brominating reagents, such as NBS (12), 3,3-dimethyl-1,4-dibromohydantoin (13), and $N$-bromosaccarine (14) yielded poorer results under similar reaction conditions. In addition, $\mathrm{NaBrO}_{3}$, a strong inorganic brominating reagent in acidic aqueous solution, did not provide satisfactory results. ${ }^{29)}$ Furthermore, the bromination of $N$-acetylphenylalanine methyl ester (18), a protected form of phenylalanine, was carried out using BICA-Na (11) under similar condition $\left(60 \% \mathrm{H}_{2} \mathrm{SO}_{4}\right.$, $0{ }^{\circ} \mathrm{C}, 2 \mathrm{~h}$ ). But only decomposed products was observed based on TLC. The same reaction in organic solvents (DMF or $\mathrm{CHCl}_{3}$ ) using various brominating reagents such as 12, 13, 14 resulted recovery of starting material (49-60\%) accompanied with decomposed products under same temperature. Even at elevated temperature $\left(80^{\circ} \mathrm{C}\right)$, or with using Lewis acid, brominating products were not obtained. ${ }^{30}$ ) Those results clearly indicated that free phenylalanine was more reactive in strong acidic aqueous solution than in organic solvent.

Bromination of L-Tyrosine Next, bromination of tyrosine (19) was attempted. In the presence of $1.1 \mathrm{eq}$ of BICA$\mathrm{Na}$ (11), mono- (20) and dibromotyrosine (21) were formed in $29 \%$ and $19 \%$ yield, accompanied with starting material recovery $(35 \%)$ (Chart 3 ). The use of 2.0 eq of BICA-Na (11), however, gave optically pure dibromotyrosine (21) selectively in $71 \%$ isolated yield. ${ }^{31)}$

Bromination of Phenylglycine HPLC analysis shows that bromination of phenylglycine (22) resulted in many products (Chart 4, Fig. 2). Surprisingly, meta-bromophenylglycine (23) was formed as a main product (44\%), accompa-

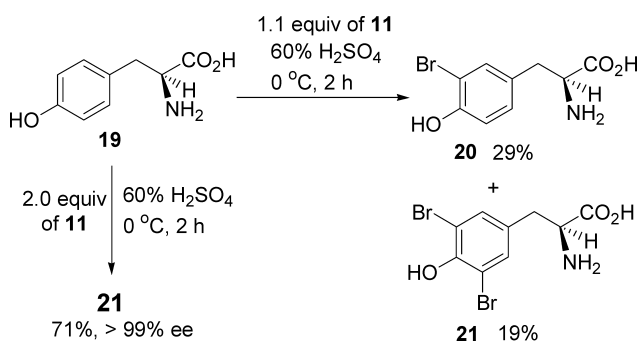

Chart 3. Bromination of L-Tyrosine (19)
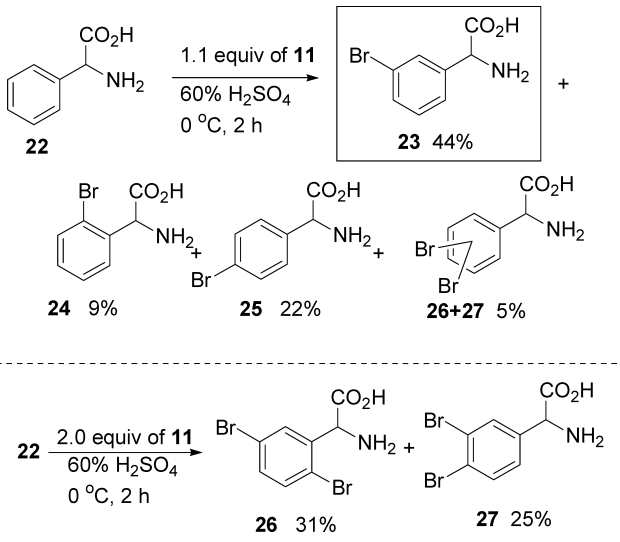

Chart 4. Bromination of $d l$-Phenylglycine (22)

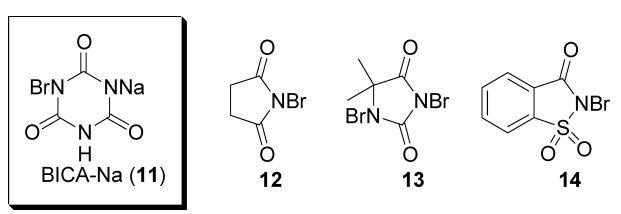

Fig. 1. Brominating Reagents

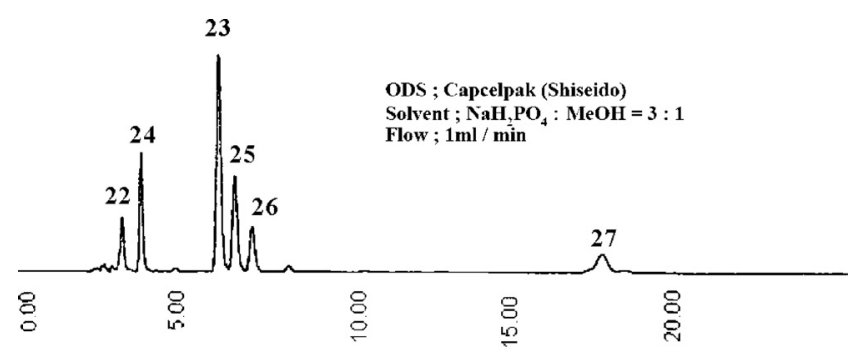

Fig. 2. HPLC Chart for the Bromination of Phenylglycine (22)

nied by ortho- $(\mathbf{2 4}, \mathbf{9 \%})$ and para-bromophenylglycine (25, $22 \%$ ), and a small amount of dibromophenylglycines $(\mathbf{2 6}+\mathbf{2 7}$, total yield $5 \%)$ after repeated purification using ODS, polymer resin, and ion-exchange resin. Interestingly, HPLC analysis revealed that only two dibromophenylglycines were formed out of six possible isomers. Based on this observation, when 2 eq of BICA-Na (11) were used, the same dibromoglycines were formed selectively, and those products could be separated easily by ODS column chromatography. The structures of the compounds were confirmed as 2,5-(26) or 3,4-dibromophenylglycine $(\mathbf{2 7})^{32)}$ based on the coupling pattern of aromatic protons and NOESY spectrum in NMR. This result was beneficial for synthesizing dibromophenylglycines with those specific substitution patterns. To identify the mechanism for this selec- 


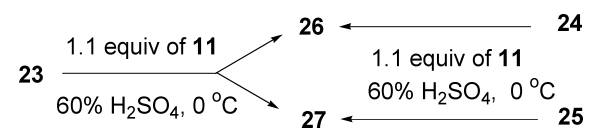

Chart 5. Results of the Bromination of Mono-bromophenylglycine (23-25)

Table 2. Bromination of 2-Phenylethylamine (28) and Benzylamine (31)

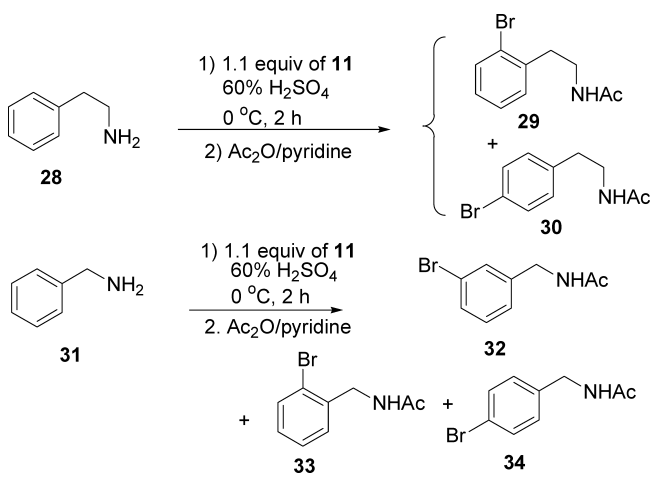

\begin{tabular}{lrccc}
\hline \hline \multirow{2}{*}{ Starting material } & \multicolumn{3}{c}{ Product yield $^{a)}$} & $\begin{array}{c}\text { Total } \\
\text { yield }\end{array}$ \\
\cline { 2 - 4 } & \multicolumn{1}{c}{$o-\mathrm{Br}$} & $m$ - $\mathrm{Br}$ & $p$ - $\mathrm{Br}$ & \\
\hline 2-Phenylethylamine (28) & $21 \%(\mathbf{2 9})$ & - & $22 \%(\mathbf{3 0})$ & $43 \%$ \\
Phenylalanine (15) & $36 \%(\mathbf{1 6})$ & - & $58 \%(\mathbf{1 7})$ & $94 \%$ \\
Benzylamine (31) & $21 \%(\mathbf{3 3})$ & $15 \%(\mathbf{3 2})$ & $16 \%(\mathbf{3 4})$ & $52 \%$ \\
Phenylglycine (22) & $9 \%(\mathbf{2 4})$ & $44 \%(\mathbf{2 3})$ & $22 \%(\mathbf{2 5})$ & $75 \%$ \\
\hline
\end{tabular}

a) Determined by NMR analysis of the crude products.

tivity, HPLC analysis of the bromination of each mono-bromophenylglycine was attempted. From ortho- (24) or parabromophenylglycine (25), 26 and $\mathbf{2 7}$ were formed as the sole products, respectively, while meta-bromophenylglycine (23) gave a mixture of $\mathbf{2 6}$ and $\mathbf{2 7}$ (Chart 5). The results show that substitution during the second bromination was controlled by the orientational effect of the bromo group.

Bromination of 2-Phenylethylamine and Benzylamine The formation of meta-substitution in the bromination of phenylglycine (22) has not been explained. Therefore, direct bromination of the corresponding amines, such as 2phenylethylamine (28) and benzylamine (31), was conducted to determine whether the reactivity and selectivity were limited to the amino acids. The reactions were carried out under similar conditions and a mixture of the products was isolated after acetylation for purification. The yields were calculated from the integration of the NMR spectrum and the results are shown in Table 2, which also contains results of the corresponding amino acids $(\mathbf{1 5}, \mathbf{2 2})$ for comparison. Bromination of 2-phenylethylamine (28) did not give meta-substituted products; instead it yielded ortho- (29) and para-substituted products (30) in 21 and $22 \%$ yields, respectively, while that of benzylamine (31) gave a meta-substituted product (32, $15 \%)$ in addition to ortho- $(\mathbf{3 3}, 21 \%)$ and para-substituted products $(34,16 \%)$. Although the substitution pattern was similar to the corresponding amino acids, the product ratios were different; the product ratio of meta-substituted product (32) from benzylamine (31) was much lower than that from an amino acid (22).

The unexpected orientation resulting from the bromination of $\mathbf{2 2}$ and $\mathbf{3 1}$ was explained by the electron-withdrawing ef- fect of the ammonium ion on the $\alpha$-alkyl side chain. This effect occurred more strongly with $\mathbf{2 2}$ than with $\mathbf{3 1}$, because the presence of a carboxyl group enhanced the electron-withdrawing effect. Therefore, the amount of meta-product from 22 was higher than that of $\mathbf{3 1}$. This electron-withdrawing effect did not appear with the $\beta$-alkyl side chain of phenylalanine (15) or 2-phenylethylamine (28), which produced only ortho- and para-products. Furthermore, the total yields of mono-bromo products from amino acids $(\mathbf{1 5}, \mathbf{2 2})$ were much higher than those from corresponding amines $(\mathbf{2 8}, \mathbf{3 1})$. These results revealed that, under the oxidative circumstance such as bromination, amino acids were more stable in strong acidic condition than the corresponding amines.

\section{Conclusion}

The present results show that amino acids can react with brominating reagent without decomposition by protonation in strong acidic media. Although the reaction gave a mixture of positional isomers, we can propose the unique synthetic methods using unprotected amino acids in aqueous media. We represent another example of the special properties of amino acids in aqueous solution.

\section{Experimental}

General All reagents and solvents were obtained commercially and used as received unless otherwise indicated. All melting points were determined on a Yanagimoto micro-melting hot stage apparatus and are uncorrected. IR spectra were recorded as $\mathrm{KBr}$ tablets (unless otherwise stated) on a JASCO FT/IR-230 spectrometer. NMR spectra were recorded on a JEOL GX-400 (400 MHz) spectrometer (unless otherwise stated) with tetramethylsilane as the internal reference. The following abbreviations were used: $s$, singlet; d, doublet; dd, double doublet; t, triplet; q, quartet; m, multiplet; br, broad; dif, diffused; Ar, aromatic. EI-Mass spectra were measured with a JEOL JMS-01SG-2 or JMS-AM-II-50 spectrometer using a direct inlet system. FAB-Mass spectra were measured with a JEOL JMS-600H spectrometer using a direct inlet system. High resolution TOFF-MS spectra were measured with LCT Premier OA-TOFF Mass (Waters) attached with ACQUITY UPLC System (Waters)

Bromination of L-Phenylalanine (15) To a solution of L-phenylalanine (15) $(165 \mathrm{mg}, 1 \mathrm{mmol})$ in $60 \% \mathrm{H}_{2} \mathrm{SO}_{4}(1.6 \mathrm{ml})$ was added BICA-Na (11) $(312 \mathrm{mg}, 1.1 \mathrm{mmol})$ at $0{ }^{\circ} \mathrm{C}$ and the reaction mixture was kept for $1 \mathrm{~h}$. Then the mixture was cautiously powdered into $\mathrm{H}_{2} \mathrm{O}(30 \mathrm{ml})$ under ice cooling, and $\mathrm{Ba}(\mathrm{OH})_{2} \cdot 8 \mathrm{H}_{2} \mathrm{O}$ was added for neutralization $(\mathrm{pH} 7)$. The resulted precipitate was removed by filtration and washed thoroughly with $\mathrm{H}_{2} \mathrm{O}$. Then the filtrate was concentrated by evaporation to about $30 \mathrm{ml}$ and subjected to reverse phase, octadesyl silica-gel (ODS) column chromatography $(20 \mathrm{~g})$ $\left(\mathrm{H}_{2} \mathrm{O}: \mathrm{MeOH}=5: 1-1: 5\right)$. The first fraction was ortho-bromophenylalanine (16) $(88.3 \mathrm{mg}, 36 \%)$. Colorless powder; $\mathrm{mp} 239-243^{\circ} \mathrm{C}$ (lit. ${ }^{28}$ ) $\left.252{ }^{\circ} \mathrm{C}\right)$. IR: $v_{\max }(\mathrm{KBr}) \mathrm{cm}^{-1}: 3433,3065,1594 ;{ }^{1} \mathrm{H}-\mathrm{NMR}(400 \mathrm{MHz}$, $\left.\mathrm{CD}_{3} \mathrm{OD}\right) \delta: 3.02(1 \mathrm{H}, \mathrm{dd}, J=10,14 \mathrm{~Hz}), 3.44(1 \mathrm{H}, \mathrm{dd}, J=5,14 \mathrm{~Hz}), 3.80$ $(1 \mathrm{H}, \mathrm{dd}, J=5,14 \mathrm{~Hz}), 7.16(1 \mathrm{H}, \mathrm{dt}, J=2,8 \mathrm{~Hz}), 7.30(1 \mathrm{H}, \mathrm{dt}, J=1,8 \mathrm{~Hz})$, $7.36(1 \mathrm{H}, \mathrm{dd}, J=2,8 \mathrm{~Hz}), 7.61(1 \mathrm{H}, \mathrm{dd}, J=1,8 \mathrm{~Hz})$; ESI-MS $m / z: 246$ $\left(\mathrm{M}^{+}+2\right), 244\left(\mathrm{M}^{+}\right), 200$ (Base Peak), 198 (BP-2); HR-MS (ESI-TOFF) $\mathrm{m} / \mathrm{z}$ Calcd for $\mathrm{C}_{9} \mathrm{H}_{10}{ }^{79} \mathrm{BrNO}_{2}$ 243.9968, Found $243.9977\left(\mathrm{M}^{+}\right) . \mathrm{C}_{9} \mathrm{H}_{10}{ }^{81} \mathrm{BrNO}_{2}$ 245.9953, Found $243.9960\left(\mathrm{M}^{+}+2\right)$. The optical purity of $\mathbf{1 6}$ were $>99 \%$ e.e. $\left[11.0 \mathrm{~min}\right.$, Chirabiotic $\mathrm{T}$ (Tokyo Kasei), EtOH $: \mathrm{H}_{2} \mathrm{O}: \mathrm{AcOH}=$ $100: 100: 1]$. para-Bromophenylalanine (17) was obtained as colorless solid (143 mg, 58\%); mp 213-216 ${ }^{\circ} \mathrm{C}\left(\right.$ lit. $^{28)} 256^{\circ} \mathrm{C}$ ); IR: $v_{\max }(\mathrm{KBr}) \mathrm{cm}^{-1}: 3428$, 3043,$1588 ;{ }^{1} \mathrm{H}-\mathrm{NMR}\left(400 \mathrm{MHz}, \mathrm{CD}_{3} \mathrm{OD}\right) \delta: 2.99(1 \mathrm{H}, \mathrm{dd}, J=8,15 \mathrm{~Hz})$, $3.25(1 \mathrm{H}, \mathrm{dd}, J=4,15 \mathrm{~Hz}), 3.75(1 \mathrm{H}, \mathrm{dd}, J=4,8 \mathrm{~Hz}), 7.22(2 \mathrm{H}, \mathrm{d}, J=6 \mathrm{~Hz})$, $7.49(2 \mathrm{H}, \mathrm{d}, J=6 \mathrm{~Hz})$; ESI-MS $m / z: 246\left(\mathrm{M}^{+}+2\right), 244\left(\mathrm{M}^{+}\right), 200$ (Base Peak); Anal. Calcd $\mathrm{C}_{9} \mathrm{H}_{10} \mathrm{BrNO}_{2} \cdot 1 / 4 \mathrm{H}_{2} \mathrm{O}: \mathrm{C}, 43.48 ; \mathrm{H}, 4.26 ; \mathrm{N}, 5.63$; Found: C, 43.08; H, 4.00; N, 5.59. The optical purity of $\mathbf{1 7}$ were $>99 \%$ e.e. [10.3 min, Chirabiotic T (Tokyo Kasei), EtOH : $\left.\mathrm{H}_{2} \mathrm{O}: \mathrm{AcOH}=100: 100: 1\right]$

Bromination of L-Tyrosine (19) 2.0 eq of BICA-Na (11): To a solution of L-tyrosine $(19,181 \mathrm{mg}, 1.0 \mathrm{mmol})$ in $60 \%$ aq. $\mathrm{H}_{2} \mathrm{SO}_{4}(8.8 \mathrm{ml})$ was added BICA-Na (11) $(568 \mathrm{mg}, 2.0 \mathrm{mmol})$ at $0{ }^{\circ} \mathrm{C}$. After stirring for $1.5 \mathrm{~h}$ at same temperature, the mixture was quenched with $\mathrm{H}_{2} \mathrm{O}(30 \mathrm{ml})$, and neutralized with solid $\mathrm{Ba}(\mathrm{OH})_{2} \cdot 8 \mathrm{H}_{2} \mathrm{O}(\mathrm{pH}=7)$. After the resulting precipitates $\left(\mathrm{BaSO}_{4}\right)$ 
were removed by filtration, the filtrate was concentrated under vacuum to about $30 \mathrm{ml}$. Then the solution was subjected to ODS column chromatography eluted with $\mathrm{H}_{2} \mathrm{O}: \mathrm{MeOH}(10: 1-1: 5)$ to give pure 3,5-dibromo-L-tyrosine $(\mathbf{2 1}, 242 \mathrm{mg}, 71 \%)$ as colorless powder; $\mathrm{mp} 221-224^{\circ} \mathrm{C}$ (lit. $^{31)} 242$ $\left.256{ }^{\circ} \mathrm{C}\right)$; IR: $v_{\max }(\mathrm{KBr}) \mathrm{cm}^{-1}: 3428,3035,1625 ;{ }^{1} \mathrm{H}-\mathrm{NMR}(400 \mathrm{MHz}$ $\left.\mathrm{CD}_{3} \mathrm{OD}\right) \delta: 2.93(1 \mathrm{H}, \mathrm{dd}, J=8,14 \mathrm{~Hz}), 3.17(1 \mathrm{H}, \mathrm{dd}, J=4,14 \mathrm{~Hz}), 3.74(1 \mathrm{H}$, dd, $J=4,8 \mathrm{~Hz}), 7.45(2 \mathrm{H}, \mathrm{s})$; ESI-MS $m / z: 342\left(\mathrm{M}^{+}+3\right), 340\left(\mathrm{M}^{+}+1\right.$ Base Peak), $338\left(\mathrm{M}^{+}-1\right)$; Anal. Calcd $\mathrm{C}_{12} \mathrm{H}_{13} \mathrm{Br}_{2} \mathrm{NO}_{4} \cdot \mathrm{H}_{2} \mathrm{O}: \mathrm{C}, 30.28 ; \mathrm{H}, 3.11 ; \mathrm{N}$, 3.92; Found: C, 30.15; H, 2.95; N, 3.87. The optical purities of 21 were $>99 \%$ e.e. $\left[6.24 \mathrm{~min}\right.$, Chirabiotic T (Tokyo Kasei), EtOH $: \mathrm{H}_{2} \mathrm{O}: \mathrm{AcOH}=$ $100: 100: 1]$.

1.1 eq of BICA-Na (11): To a solution of L-tyrosine (19, $181 \mathrm{mg}$, $1.0 \mathrm{mmol})$ in $60 \%$ aq. $\mathrm{H}_{2} \mathrm{SO}_{4}(8.8 \mathrm{ml})$ was added BICA-Na (11) $(312 \mathrm{mg})$ in one portion at $0{ }^{\circ} \mathrm{C}$. After stirring for $2 \mathrm{~h}$ at same temperature, the mixture was quenched with $\mathrm{H}_{2} \mathrm{O}(20 \mathrm{ml})$. Then the mixture was neutralized with $\mathrm{Ba}(\mathrm{OH})_{2}(\mathrm{pH}=7)$ and the resulting precipitates $\left(\mathrm{BaSO}_{4}\right)$ was removed by filtration. The filtrate was concentrated under vacuum to about $30 \mathrm{ml}$. Then the solution was subjected to weak basic ionic exchange resin (IRA96SB, $50 \mathrm{ml}$ ) and eluted with water $(21)$ to remove remaining inorganic compounds and $5 \%$ aq. AcOH-MeOH $(20: 1,350 \mathrm{ml})$ to elute the mixture of amino acids $(20,21)$. After evaporation of the solvent, the resulting residue $(293 \mathrm{mg})$ was subjected to synthetic resin (SP20SS, $50 \mathrm{ml}$ ). The first fraction was 3-bromoL-tyrosine $(\mathbf{2 0}, 75 \mathrm{mg}, 29 \%)$ as a colorless powder. $\mathrm{mp} 232-234{ }^{\circ} \mathrm{C}$ (lit. ${ }^{31}$ $\left.224^{\circ} \mathrm{C}\right) .{ }^{1} \mathrm{H}-\mathrm{NMR}\left(400 \mathrm{MHz}, \mathrm{CD}_{3} \mathrm{OD}\right) \delta: 2.91(1 \mathrm{H}, \mathrm{dd}, J=8,15 \mathrm{~Hz}), 3.17$ $(1 \mathrm{H}, \mathrm{dd}, J=5,15 \mathrm{~Hz}), 3.70(1 \mathrm{H}, \mathrm{dd}, J=5,8 \mathrm{~Hz}), 6.86(1 \mathrm{H}, \mathrm{d}, J=8 \mathrm{~Hz}), 7.10$ $(1 \mathrm{H}, \mathrm{dd}, J=2,8 \mathrm{~Hz}), 7.42(1 \mathrm{H}, \mathrm{d}, J=2 \mathrm{~Hz})$. The second fraction was L-3,5dibromotyrosine $(\mathbf{2 1}, 65 \mathrm{mg}, 19 \%)$. The third fraction was recovered starting L-tyrosine (65 mg, 35\%).

Bromination of DL-Phenylglycine (22) $d l$-Phenylglycine $(22,152 \mathrm{mg}$ $1 \mathrm{mmol})$ was dissolved in $60 \%$ aq. $\mathrm{H}_{2} \mathrm{SO}_{4}(10 \mathrm{ml})$. To this solution was added BICA-Na $(\mathbf{1 1}, 312 \mathrm{mg}, 1.1 \mathrm{eq})$ under $5^{\circ} \mathrm{C}$, then the mixture was stirred for $2.5 \mathrm{~h}$ under ice cooling. After dilution with $\mathrm{H}_{2} \mathrm{O}(30 \mathrm{ml})$, $\mathrm{Ba}(\mathrm{OH})_{2} \cdot 8 \mathrm{H}_{2} \mathrm{O}(36 \mathrm{~g})$ was added to the mixture for neutralization $(\mathrm{pH} 6-7)$ under ice cooling. Then the resulted precipitate $\left(\mathrm{BaSO}_{4}\right)$ was removed by filtration and washed with small proportion of water. The combined filtrate was passed through weak basic ion-exchange resin [ $80 \mathrm{ml}$, Amberlite IRA96SB, (Organo)] and the resin was washed with water $(700 \mathrm{ml})$ in order to remove inorganic compounds completely. Then elution with $5 \% \mathrm{AcOH}$ aq. : $\mathrm{MeOH}(=20: 1,700 \mathrm{ml})$ gave the crude product $(198 \mathrm{mg})$ as a white solid after evaporation of solvent. The crude product $(198 \mathrm{mg})$ was purified repeatedly by using synthetic resin $[80 \mathrm{ml}$, Sepabeads SP20SS (Mitsubishi Chemical Co.) elution with $\mathrm{H}_{2} \mathrm{O}$ ] and ODS column chromatography [Ultra Pack ODS-A-40B (Yamazen), elution with $\mathrm{H}_{2} \mathrm{O}-10 \%$ aq. $\mathrm{MeOH}$ ], to give pure 24 (14 mg), 23 (41 mg), and a mixture of 26 and 27 (16 mg). 25 was purified by repeated ODS chromatography from the mixture of $\mathbf{2 4}$ and $\mathbf{2 5}$ $(107 \mathrm{mg})$. Product ratios of each inseparable fractions [22+24 $(22 \mathrm{mg})$, $\mathbf{2 3}+\mathbf{2 4}(4 \mathrm{mg})$, and $\mathbf{2 3}+\mathbf{2 5}(107 \mathrm{mg})]$ were determined by the integration of aromatic protons of the NMR spectrum. The calculated combined yields were shown in the Chart 4

3-Bromophenylglycine (23): White powder, mp $231-232{ }^{\circ} \mathrm{C}$. IR $(\mathrm{KBr})$ : $3446,1635,1582 \mathrm{~cm}^{-1}$. ${ }^{1} \mathrm{H}-\mathrm{NMR}\left(400 \mathrm{MHz}, \mathrm{CD}_{3} \mathrm{OD}\right) \delta: 7.69(\mathrm{t}, 1 \mathrm{H}$, $J=1.6 \mathrm{~Hz}), 7.54$ (ddd, $1 \mathrm{H}, J=8.0,1.6,0.9 \mathrm{~Hz}), 7.46$ (br d, $1 \mathrm{H}, J=8 \mathrm{~Hz}), 7.33$ $(\mathrm{t}, 1 \mathrm{H}, J=8.0 \mathrm{~Hz}), 4.56(\mathrm{~s}, 1 \mathrm{H})$. MS (ESI): $m / z: 230\left[\mathrm{M}^{+}\right]^{+}, 232\left[\mathrm{M}^{+}+2\right]^{+}$ HR-MS (ESI-TOFF) $m / z$ Calcd for $\mathrm{C}_{8} \mathrm{H}_{9}{ }^{79} \mathrm{BrNO}_{2} 229.9817$, Found 229.9829 $\left(\mathrm{M}^{+}\right)$. Calcd for $\mathrm{C}_{8} \mathrm{H}_{9}{ }^{81} \mathrm{BrNO}_{2} 231.9796$, Found $231.9808\left(\mathrm{M}^{+}+2\right)$.

2-Bromophenylglycine (24): White powder, $\mathrm{mp}>250^{\circ} \mathrm{C}$. IR $(\mathrm{KBr})$ 3436, 1662, $1590 \mathrm{~cm}^{-1}$. ${ }^{1} \mathrm{H}-\mathrm{NMR}\left(400 \mathrm{MHz}, \mathrm{CD}_{3} \mathrm{OD}\right) \delta: 7.69(\mathrm{dd}, 1 \mathrm{H}$, $J=8.0,1.2 \mathrm{~Hz}), 7.54(\mathrm{dd}, 1 \mathrm{H}, J=8.0,1.6 \mathrm{~Hz}), 7.41(\mathrm{dt}, 1 \mathrm{H}, J=8.0,1.2 \mathrm{~Hz})$, $7.30(\mathrm{dt}, 1 \mathrm{H}, J=8.0,1.6 \mathrm{~Hz}), 5.10(\mathrm{~s}, 1 \mathrm{H}) . \mathrm{MS}(\mathrm{ESI}): m / z: 230\left[\mathrm{M}^{+}\right]^{+}, 232$ $\left[\mathrm{M}^{+}+2\right]^{+}$. HR-MS (ESI-TOFF) $\mathrm{m} / \mathrm{z}$ Calcd for $\mathrm{C}_{8} \mathrm{H}_{9}{ }^{79} \mathrm{BrNO}_{2} 229.9817$, Found $229.9821\left(\mathrm{M}^{+}\right)$. Calcd for $\mathrm{C}_{8} \mathrm{H}_{9}{ }^{81} \mathrm{BrNO}_{2} 231.9796$, Found 231.9804 $\left(\mathrm{M}^{+}+2\right)$.

4-Bromophenylglycine (25): White powder. $\mathrm{mp}>250^{\circ} \mathrm{C}$. IR $(\mathrm{KBr})$ : $3438,1635,1581 \mathrm{~cm}^{-1}$. ${ }^{1} \mathrm{H}-\mathrm{NMR}\left(400 \mathrm{MHz}, \mathrm{CD}_{3} \mathrm{OD}\right) \delta: 7.56(\mathrm{~d}, 2 \mathrm{H}$ $J=8.4 \mathrm{~Hz}$ ), 7.39 (d, $2 \mathrm{H}, J=8.4 \mathrm{~Hz}), 4.56$ (s, 1H). MS (ESI): $m / z: 230[\mathrm{M}]^{+}$, $232[\mathrm{M}+2]^{+}$. The structure of was confirmed by the comparison of commercially available 25 .

2,5-Dibromophenylglycine (26): White powder, mp $170-172^{\circ} \mathrm{C}$. IR (KBr): 3441, $1625 \mathrm{~cm}^{-1}$. ${ }^{1} \mathrm{H}-\mathrm{NMR}\left(400 \mathrm{MHz}, \mathrm{CD}_{3} \mathrm{OD}\right) \delta: 7.62$ (d, $1 \mathrm{H}$, $J=2.0 \mathrm{~Hz}), 7.51(\mathrm{~d}, 1 \mathrm{H}, J=8.4 \mathrm{~Hz}), 7.36(\mathrm{dd}, 1 \mathrm{H}, J=8.4,2.0 \mathrm{~Hz}), 4.91(1 \mathrm{H}$, s). MS (ESI): $m / z: 308\left[\mathrm{M}^{+}\right]^{+}, 310\left[\mathrm{M}^{+}+2\right]^{+}, 312\left[\mathrm{M}^{+}+4\right]^{+}$. Elemental analysis was carried out as $\mathrm{N}$-acetyl-2,5-dibromophenyl-glycine methyl ester: white powder, mp $130-131^{\circ} \mathrm{C}$. Anal. Calcd for $\mathrm{C}_{11} \mathrm{H}_{11} \mathrm{Br}_{2} \mathrm{NO}_{3}$ : C, 36.19; H, 3.04; N, 3.84. Fond: C, 36.39; H, 3.16; N, 3.36.
3,4-Dibromophenylglycine (27): White powder, mp $193-195^{\circ} \mathrm{C}$. IR (KBr): 3431, $1636 \mathrm{~cm}^{-1} .{ }^{1} \mathrm{H}-\mathrm{NMR}\left(400 \mathrm{MHz}, \mathrm{CDCl}_{3}\right) \delta: 7.83$ (d, $1 \mathrm{H}$ $J=2.0 \mathrm{~Hz}), 7.72(\mathrm{~d}, 1 \mathrm{H}, J=8.0 \mathrm{~Hz}), 7.35(\mathrm{dd}, 1 \mathrm{H}, J=8.0,2.0 \mathrm{~Hz}), 5.17(1 \mathrm{H}$, s). MS (ESI): $m / z: 308\left[\mathrm{M}^{+}\right]^{+}, 310\left[\mathrm{M}^{+}+2\right]^{+}, 312\left[\mathrm{M}^{+}+4\right]^{+}$. Elemental analysis was carried out as $\mathrm{N}$-acetyl-3,4-dibromophenylglycine methyl ester: white powder, mp $115-117^{\circ} \mathrm{C}$. Anal. Calcd for $\mathrm{C}_{11} \mathrm{H}_{11} \mathrm{Br}_{2} \mathrm{NO}_{3}$ : C, 36.19; $\mathrm{H}$, 3.04; N, 3.84. Found: C, 36.12; H, 3.06; N, 3.33.

Bromination of 2-Phenylethylamine (28) To a solution of 2phenylethyamine $(\mathbf{2 8}, 126 \mu \mathrm{l}, 1.0 \mathrm{mmol})$ in $60 \%$ aq. $\mathrm{H}_{2} \mathrm{SO}_{4}(2.0 \mathrm{ml})$ was added BICA-Na (11) $(312 \mathrm{mg}, 1.0 \mathrm{mmol})$ in one portion at $0{ }^{\circ} \mathrm{C}$, and stirred for $2.5 \mathrm{~h}$ at same temperature. After addition of $\mathrm{H}_{2} \mathrm{O}(5.0 \mathrm{ml})$, the mixture was basified with $30 \% \mathrm{NaOH}(\mathrm{pH}=13)$ and extracted with $\mathrm{Et}_{2} \mathrm{O}$ for 3 times. The combined organic layer was washed successively with sat. $\mathrm{NaHCO}_{3}$ and sat. $\mathrm{NaCl}$, and dried over $\mathrm{MgSO}_{4}$. After evaporation of the solvent, resulting yellow oil $(118 \mathrm{mg})$ was acetylated with $\mathrm{Ac}_{2} \mathrm{O}(0.50 \mathrm{ml})$ in pyridine $(1.0 \mathrm{ml})$ at room temperature for $2 \mathrm{~h}$. Then the mixture was quenched with water, acidified with $10 \% \mathrm{HCl}$, and extracted with $\mathrm{Et}_{2} \mathrm{O}$ for 3 times. Combined organic layer was washed with successively with sat. $\mathrm{NaHCO}_{3}$, sat. $\mathrm{NaCl}$, and dried over $\mathrm{MgSO}_{4}$. After evaporation of the solvent, the resulting pale yellow oil $(105 \mathrm{mg})$ was measured NMR spectrum. The intensity of the integration of benzyl proton at $2.77 \mathrm{ppm}(\mathrm{p}-)$ and $2.98(\mathrm{o}-) \mathrm{ppm}$ showed that the yields of the 29 and $\mathbf{3 0}$ were $21 \%$ and $22 \%$ respectively. Each product was confirmed by the comparison of the pure authentic samples synthesized by us (see below).

Bromination of Benzylamine (31) To a solution of benzylamine (31, $109 \mu \mathrm{l}, 1.0 \mathrm{mmol})$ in $60 \%$ aq. $\mathrm{H}_{2} \mathrm{SO}_{4}(2.0 \mathrm{ml})$ was added BICA-Na (11) $(312 \mathrm{mg}, 1.0 \mathrm{mmol})$ in one portion at $0{ }^{\circ} \mathrm{C}$, and the reaction mixture was stirred for $2.5 \mathrm{~h}$ at same temperature. The crude product $(108 \mathrm{mg})$ was obtained as yellow oil by the procedure described for the bromination of 2 phenylethylamine (28). This oil was acetylated as described above to give the mixture of acetylated products $(118 \mathrm{mg})$, which was measured NMR spectrum to determine the yields. The intensities of the integration of benzyl proton at $4.51 \mathrm{ppm}(o-), 4.42 \mathrm{ppm}(m-)$, and $4.39(p-)$ ppm showed that the yields of the 33, 32, and 34 were $21 \%, 15 \%$, and $16 \%$ respectively. Each product was confirmed by the comparison of the pure authentic sample synthesized by us (see below).

$N$-Acetyl-2-(2-bromophenyl)ethylamine (29): Pale yellow oil; IR $v_{\max }$ $(\mathrm{KBr}) \mathrm{cm}^{-1}: 3288,1652 ;{ }^{1} \mathrm{H}-\mathrm{NMR}\left(400 \mathrm{MHz}, \mathrm{CDCl}_{3}\right) \delta: 1.96(3 \mathrm{H}, \mathrm{s}), 2.98$ $(2 \mathrm{H}, \mathrm{t}, J=7 \mathrm{~Hz}), 3.53(2 \mathrm{H}, \mathrm{q}, J=7 \mathrm{~Hz}), 5.91(1 \mathrm{H}, \mathrm{br} \mathrm{s}), 7.1(2 \mathrm{H}, \mathrm{m}), 7.2(2 \mathrm{H}$, m); Anal. Calcd for $\mathrm{C}_{10} \mathrm{H}_{12} \mathrm{BrNO}$ : C, 49.61; H, 5.00; N, 5.79. Found: C, 49.50; H, 5.24; N, 5.56.

$\mathrm{N}$-Acetyl-2-(4-bromophenyl)ethylamine (30): Colorless needles; $\mathrm{mp}$ $105-106^{\circ} \mathrm{C}$ (from hexane and AcOEt). IR $v_{\max }(\mathrm{KBr}) \mathrm{cm}^{-1}: 3294,1639$ ${ }^{1} \mathrm{H}-\mathrm{NMR}\left(400 \mathrm{MHz}, \mathrm{CDCl}_{3}\right) \delta: 1.95(3 \mathrm{H}, \mathrm{s}), 2.77(2 \mathrm{H}, \mathrm{t}, J=7 \mathrm{~Hz}), 3.48(2 \mathrm{H}$, q, $J=7 \mathrm{~Hz}), 5.39(1 \mathrm{H}$, br s $), 7.08(2 \mathrm{H}, \mathrm{d}, J=6 \mathrm{~Hz}), 7.44(2 \mathrm{H}, \mathrm{d}, J=6 \mathrm{~Hz}) ; \mathrm{MS}$ (EI) $m / z: 243(\mathrm{M}+2)^{+}, 241(\mathrm{M})^{+}, 184(\mathrm{bp})$; Anal. Calcd for $\mathrm{C}_{10} \mathrm{H}_{12} \mathrm{BrNO}: \mathrm{C}$, 49.61; H, 5.00; N, 5.79. Found: C, 49.67; H, 5.06; N, 5.44.

$\mathrm{N}$-Acetyl-3-bromobenzylamine (32): Colorless needles; mp $76-78^{\circ} \mathrm{C}$ (from hexane-AcOEt). IR: $v_{\max }(\mathrm{KBr}) \mathrm{cm}^{-1}: 3288,1638 ;{ }^{1} \mathrm{H}-\mathrm{NMR}$ $\left(400 \mathrm{MHz}, \mathrm{CDCl}_{3}\right) \delta: 2.04(3 \mathrm{H}, \mathrm{s}), 4.41(2 \mathrm{H}, \mathrm{d}, J=6 \mathrm{~Hz}), 5.75(1 \mathrm{H}, \mathrm{brs})$, $7.21(2 \mathrm{H}, \mathrm{m}), 7.42(2 \mathrm{H}, \mathrm{m})$; MS (EI) $m / z: 227(\mathrm{M})^{+}, 229(\mathrm{M}+2)^{+}, 106$ (Base Peak); Anal. Calcd for $\mathrm{C}_{9} \mathrm{H}_{10}$ BrNO: C, 47.39; H, 4.42; N, 6.14. Found: C, 47.64; H, 4.47; N, 5.73.

$\mathrm{N}$-Acetyl-2-bromobenzylamine (33): Colorless needles; mp $82-84^{\circ} \mathrm{C}$ (from hexane-AcOEt); IR $v_{\max }(\mathrm{KBr}) \mathrm{cm}^{-1}$ : 3266, 1640; ${ }^{1} \mathrm{H}-\mathrm{NMR}$ $\left(400 \mathrm{MHz}, \mathrm{CDCl}_{3}\right) \delta: 2.02(3 \mathrm{H}, \mathrm{s}), 4.51(2 \mathrm{H}, \mathrm{d}, J=6 \mathrm{~Hz}), 5.96(1 \mathrm{H}, \mathrm{brs})$, $7.15(1 \mathrm{H}, \mathrm{dt}, J=8,2 \mathrm{~Hz}), 7.29(1 \mathrm{H}, \mathrm{dt}, J=8,1 \mathrm{~Hz}), 7.40(1 \mathrm{H}, \mathrm{dd}, J=8,2 \mathrm{~Hz})$, $7.55(1 \mathrm{H}, \mathrm{dd}, J=8,1 \mathrm{~Hz})$; Anal. Calcd for $\mathrm{C}_{9} \mathrm{H}_{10} \mathrm{BrNO}$ : C, 47.39; H, 4.42; N, 6.14. Found: C, 47.49; H, 4.50; N, 5.80.

$\mathrm{N}$-Acetyl-4-bromobenzylamine (34): Colorless needles; mp $123-125^{\circ} \mathrm{C}$ (from hexane-AcOEt); IR: $v_{\max }(\mathrm{KBr}) \mathrm{cm}^{-1}: 3279,1639 ;{ }^{1} \mathrm{H}-\mathrm{NMR}$ $\left(400 \mathrm{MHz}, \mathrm{CDCl}_{3}\right) \delta: 2.03(3 \mathrm{H}, \mathrm{s}), 4.39(2 \mathrm{H}, \mathrm{d}, J=6 \mathrm{~Hz}), 5.70(1 \mathrm{H}, \mathrm{brs})$, $7.16(2 \mathrm{H}, \mathrm{d}, J=9 \mathrm{~Hz}), 7.46(2 \mathrm{H}, \mathrm{d}, J=9 \mathrm{~Hz})$. MS (EI) $m / z: 227(\mathrm{M})^{+}, 229$ $(\mathrm{M}+2)^{+}, 106$ (Base Peak); Anal. Calcd for $\mathrm{C}_{9} \mathrm{H}_{10} \mathrm{BrNO}$ : C, 47.39; H, 4.42; N, 6.14. Found: C, 47.56; H, 4.44; N, 5.72.

Acknowledgments This work was supported by a Grant-in-Aid for Scientific Research (17590229-3668) from the Ministry of Education, Culture, Sports, Science and Technology, Japan (MEXT), and by "Open Research Center" project for private university matching fund subsidy from MEXT, and also supported by a Uehara Memorial Foundation. We are also grateful to Mr. H. Kamakura (Division of Pharmacognosy and Phytochemistry, National Institute of Health Science) for measurement of high resolution TOFF-MASS 


\section{References and Notes}

1) Barrett G. C., "Chemistry and Biochemistry of Amino Acids," ed. by Barrett G. C., Chapman and Hall, London, 1985, pp. 354-375.

2) Hughes D. L., Bergan J. J., Grabowski E. J. J., J. Org. Chem., 51, 2579-2585 (1986).

3) Hashimoto M., Eda Y., Osanai Y., Iwai T., Aoki S., Chem. Lett., 1986, 893 -897 (1986).

4) Grigg R., Henderson D., Hudson A. J., Tetrahedron Lett., 30, 28412844 (1989).

5) Dangel B. D., Johnson J. A., Sames D., J. Am. Chem. Soc., 123, $8149-8150$ (2001).

6) Laval G., Golding B. T., Synlett, 2003, 542-546 (2003).

7) One of the most successful examples of synthetically useful reactions using free amino acids is deamination: Brewster P., Hiron F., Ingold C. K., Rao P. A. D. S., Nature (London), 166, 179 (1950).

8) This reaction was elegantly applied to the synthesis of optically active ribose: Koga K., Taniguchi M., Yamada S., Tetrahedron, 30, 35473551 (1974).

9) Recently, there have been many reports for asymmetric synthesis using free amino acids as organocatalyst. Recent review: Dalko P. I., Moisan L., Angew. Chem. Int. Ed., 43, 5138-5175 (2004).

10) Recently, there have been many reports for asymmetric synthesis using free amino acids as organocatalyst. Recent review: Allemann C., Gordillo R., Clemente F. R., Cheong P. H.-Y., Houk K. N., Acc. Chem. Res., 37, 558-569 (2004).

11) Recently, there have been many reports for asymmetric synthesis using free amino acids as organocatalyst. Recent review: Saito S., Yamamoto H., Acc. Chem. Res., 37, 570-579 (2004).

12) Coppola G. M., Schuster H. F., "Asymmetric Synthesis. Construction of Chiral Molecules Using Amino Acids," A Wiley-Interscience Publication, John Wiley and Sons, New York, 1987.

13) Recent selected example: Ma D., Xia C., Jiang J., Zhang J., Org. Lett., 3, 2189-2190 (2001).

14) Recent selected example: Yoon C. H., Flanigan D. L., Chong B.-D., Jung K. W., J. Am. Chem. Soc., 67, 6582-6984 (2002).

15) Recent selected example: Wijdeven M. A., Botman P. N. M., Wijtmans R., Schoemaker R., Rutjes F. P. J. T., Blaauw R. H., Org. Lett., 7, 4005-4007 (2005).

16) Yokoyama Y., Hikawa H., Mitsuhashi M., Uyama A., Murakami Y.,
Tetrahedron Lett., 40, 7803-7806 (1999).

17) Yokoyama Y., Hikawa H., Mitsuhashi M., Uyama A., Hiroki H., Murakami Y., Eur. J. Org. Chem., 2004, 1244-1253 (2004).

18) "Palladium Reagents in Organic Synthesis," ed. by Heck R. F., Academic Press, New York, 1985

19) Konigsberg N., Stevenson G., Luck J. M., J. Biol. Chem., 235, 13411345 (1960).

20) Ramachandran M. S., Easwaramoorthy D., Rajasingh V., Vivekanandam T. S., Bull. Chem. Soc. Jpn., 63, 2397-2403 (1990)

21) Gopalankrishnan G., Hogg J. L., J. Org. Chem., 50, 1206-1212 (1985).

22) Ramachandran M. S., Easwaramoorthy D., Rajasingh V., Vivekanandam T. S., Bull. Chem. Soc. Jpn., 63, 2397-2403 (1990).

23) It has been reported that bromination of 1,3-dimethoxycarbonylbenzene gave 5-bromo-1,3-dimethoxycarbonylbenzene in $84 \%$ yield at $40{ }^{\circ} \mathrm{C}$ under $96 \% \mathrm{H}_{2} \mathrm{SO}_{4}$ : Suzuki H., Hashiba I., Shimada M. Sugiyama Y., Jpn. Kokai Tokkyo Koho JP 2000219681 (2000).

24) It has been reported that bromination of 1,3-dimethoxycarbonylbenzene gave 5-bromo-1,3-dimethoxycarbonylbenzene in $84 \%$ yield at $40{ }^{\circ} \mathrm{C}$ under $96 \% \mathrm{H}_{2} \mathrm{SO}_{4}$ : Suzuki H., Nagai M., Myojo T., Hashiba I., Jpn. Kokai Tokkyo Koho JP 2001122823 (2001).

25) Okada Y., Yokozawa M., Akiba M., Oishi K., O-kawa K., Akeboshi T., Kawamura Y., Inokuma S., Nakamura Y., Nishimura J., Org. Biomol. Chem., 1, 2506-2511 (2003).

26) Sumida T., Kikuchi S., Imafuku K., Synth. Commun., 34, 4273-4284 (2004).

27) Yokoyama Y., Hikawa H., Murakami Y., J. Chem. Soc., Perkin Trans. 1, 2001, 1431-1434 (2001).

28) Faulstich H., Smith H. O., Zobeley S., Liebigs. Ann. Chem., 1973 $765-771$ (1973).

29) Complex mixture including mono- and dibrominated products was obtained accompanied with serious decomposition.

30) Addition of Lewis acid, $\mathrm{FeCl}_{3}$, was also ineffective in the reaction of NBS in $\mathrm{CHCl}_{3}\left(0^{\circ} \mathrm{C}\right)$ to recover the starting material.

31) Dibromotyrosine was known to be prepared by the reaction with $\mathrm{Br}_{2}$ in good yield: Kaneko T., J. Chem. Soc. Jpn., 59, 433- 439 (1938).

32) Unfortunately, when L-phenylglycine was used, the obtained products $\mathbf{2 7}$ and $\mathbf{2 8}$ were completely racemized. 